\title{
FUNCTIONAL ACTIVITY OF BLOOD NEUTROPHILES IN ACUTE INFLAMMATORY DISEASES OF THE ABDOMINAL ORGANS AND ABDOMINAL TUBERCULOSIS
}

\author{
V. Akimova, L. Lapovets, N. Lapovets, O. Tsymbala
}

\begin{abstract}
The diagnosis of various pathomorphological forms of acute appendicitis (AA), acute mesadenitis (AM), and abdominal tuberculosis (AT) remains an urgent problem in medicine. Neutrophilic granulocytes are the first link in the nonspecific immune response to inflammation, which is mediated by phagocytosis and intracellular bactericidal systems. Therefore, the research aimed to establish the features of the functional state of neutrophilic granulocytes in the blood of patients with AA, AM, and AT.

Materials and methods. 30 practically healthy, 27 patients with AM, 40 patients with acute phlegmonous appendicitis were examined; 20 patients with acute gangrenous appendicitis, 30 patients with AT. The phagocytic activity of neutrophils in the test with latex granules, redox activity (spontaneous HCT test), cationic lysosomal proteins in the cytochemical test with bromine phenol blue was determined in the blood.

Results. Phagocytic activity of neutrophils in patients with destructive forms of AA and AT was lower, and in the group of patients with AM - did not differ from control values. The phagocytic index of neutrophils in patients with destructive forms of $A A$ was 1.5 times lower ( $p<0.05$ ), and the phagocytic number in patients with gangrenous AA was 1.7 times lower than in healthy individuals ( $p<0.05)$. In patients with AM, the percentage of HCTpositive neutrophils was 1.3 times higher, in patients with destructive forms of AA and AT - 2 times higher than in healthy groups $(p<0.05)$. The number of neutrophils containing cationic lysosomal proteins was also higher in destructive forms of $A A$, and in AM and AT - did not differ from the value in the control group.

Conclusions. It has been established that peripheral blood neutrophils in conditions of acute destructive inflammation and abdominal tuberculosis have reduced absorption capacity with simultaneous significant activation of redox processes. Cytochemical tests to detect the phagocytic and metabolic activity of blood neutrophils are available and highly informative for the diagnosis and prediction of inflammation, as well as for the differential diagnosis of bacterial and viral diseases
\end{abstract}

Keywords: neutrophils, phagocytosis, NBT test, cationic lysososmal proteins, appendicitis, abdominal tuberculosis

Copyright (C) 2020, V. Akimova, L. Lapovets, N. Lapovets, O. Tsymbala.

This is an open access article under the CC BY license (http://creativecommons.org/licenses/by/4.0).

\section{Introduction}

Abdominal pain is the most common reason for seeking medical attention [1]. Among the inflammatory diseases of the abdominal organs (AO), which are accompanied by acute abdominal pain, the most common are gallstone disease and acute appendicitis (AA). Timely diagnosis of various pathomorphological forms of AA remains an urgent problem in medicine. Despite numerous studies, the problem of differential diagnosis of abdominal diseases of chronic nature (abdominal tuberculosis), acute nonspecific mesenteric lymphadenitis (AM), which can be treated conservatively, with acute destructive appendicitis that requires surgery. The incidence of tuberculosis in Ukraine and in the world has increased significantly over the past decade, disseminated and extrapulmonary forms of tuberculosis have become widespread. The most commonly AO is affected with infection, and AT is often diagnosed during surgery for "acute" abdomen $[2,3]$.

At the present stage of development of science is relevant to consider the development of diseases from the standpoint of typical pathological processes, which is inflammation [4]. Inflammation and ischemia are pathophysiological mechanisms of abdominal pain. In the im- mune response cascade, neutrophilic granulocytes are the first link in the nonspecific inflammatory response [5]. Their main function is the intracellular killing of foreign objects - phagocytosis. Although the lifespan of neutrophils is short after entering the inflammatory zone, inflammatory signals are able to prolong the life of cells, and they release inflammatory mediators and control inflammation [6, 7]. Timely and correct assessment of the functional state of the effector link of nonspecific immune defence in the conditions of urgent surgical pathology is one of the important criteria for choosing or modifying treatment tactics $[8,9]$. It is also important to identify adequate laboratory tests that would be available and allow to assess the activity of neutrophils in inflammatory conditions, and this will be an auxiliary laboratory criterion in a comprehensive examination of the patient. The functional activity of neutrophilic granulocytes is determined by the absorption capacity, the activity of redox processes and the content of cationic lysosomal proteins [10].

The aim of the study was to establish the features of the functional state of neutrophilic granulocytes in the blood of patients with acute appendicitis and abdominal tuberculosis. 


\section{Materials and methods}

30 practically healthy persons and 117 patients with acute abdominal diseases and abdominal tuberculosis were examined. The group of patients with AM consisted of 27 people, whose average age was $32.1 \pm 1.56$ years; patients with acute phlegmonous appendicitis (APA) 40 people; on acute gangrenous appendicitis (AGA) 20 people (mean age of patients $46.11 \pm 2.48$ years). The examinations were performed on the basis of the first surgical department of the Lviv Emergency Hospital. The blood of 30 patients with AT (patients of the Pulmonary Health Center and the Lviv Regional Hospital for Extrapulmonary Forms of Tuberculosis), with different foci of localization of the process (mean age $35 \pm 2.6$ years) was also examined. All surveys were conducted in the period 2007-2017.

The phagocytic activity of neutrophils in the blood was determined using latex granules $(D=1-3 \mu \mathrm{m}$, DIA-M, RF) as the object of phagocytosis and the phagocytic index was calculated (PI) and phagocytic number (PN) [10]. Determination of the total redox activity of neutrophils was performed in a spontaneous test for the reduction of nitro blue tetrazolium (NBTtest) by the method of Park B.H. in modification Bajora Y. I. Detection of cationic lysosomal neutrophil proteins (CLP) by the method of Shubich M.G. The number of NBT-positive and CLP-positive neutrophils and the cytochemical coefficient was determined $\left(\mathrm{NBT}_{\mathrm{CCC}}\right.$, CLP $_{\text {CCC }}$ [10].

Patients were selected taking into account measures to ensure the safety of the patient's health, respect for human rights, human dignity and moral and ethical standards in accordance with the principles of the
Helsinki Declaration of Human Rights, the Council of Europe Convention on Human Rights and Biomedicine and relevant laws of Ukraine. The Ethics Commission of the Lviv National Medical University named after Danylo Halytskyi did not find any violations of moral and ethical norms during the study (minutes of the meeting No. 3 of March 19, 2018).

Statistical processing of the research results was performed using the methods of parametric (variational) statistics in compliance with the conditions for estimating the type of distribution. The results are presented in the form of the average statistical value of the indicator and the error of the average $\mathrm{M} \pm \mathrm{m}$. The probability of the obtained results was evaluated by Student's criterion and Mann-Whitney. The STATISTICA 2006 computer software package was used for statistical processing of the material.

\section{Research results}

In the analysis of the functional state of neutrophilic granulocytes in patients with acute inflammatory diseases AO and AT, deviations from the control values of a number of functional parameters of these cells were found. Phagocytic activity of neutrophils in patients with destructive forms of AA and blood pressure was lower, and in the group of patients with AM - did not differ from control values. Thus, the PI of neutrophils in patients with destructive forms of acute appendicitis was 1.5 times lower $(\mathrm{p}<0.05)$, and PN (phagocytic number) in patients with gangrenous form AA was 1.7 times lower than in healthy individuals $(\mathrm{p}<0.05)$ (Table 1$)$

The results of the study of the functional state of neutrophils are presented in Table 1.

Table 1

Indicators of functional activity of neutrophilic granulocytes of peripheral blood in patients with AO acute diseases and $\mathrm{AT}, \mathrm{M} \pm \mathrm{m}$

\begin{tabular}{|c|c|c|c|c|c|}
\hline \multirow[b]{2}{*}{$\begin{array}{l}\text { Indicator, } \\
\text { units }\end{array}$} & \multicolumn{5}{|c|}{ Study groups, number of surveyed (n) } \\
\hline & $\begin{array}{c}\text { Control group, } \\
n=36\end{array}$ & $\mathrm{AM}, \mathrm{n}=27$ & APA, $n=26$ & $\mathrm{AGA}, \mathrm{n}=20$ & $\mathrm{AT}, \mathrm{n}=28$ \\
\hline $\mathrm{PI}, \%$ & $62.9 \pm 4.3$ & $65.3 \pm 2.5$ & $40.9 \pm 2.3^{*}$ & $41.4 \pm 2.2^{*}$ & $52.5 \pm 2.6^{*} \#^{\wedge}$ \\
\hline PN, units & $6.9 \pm 0.5$ & $5.0 \pm 0.2$ & $3.9 \pm 0.1 * \#$ & $5.0 \pm 0.4 \#$ & $5.8 \pm 0.4 \#$ \\
\hline NBT, $\%$ & $23.3 \pm 6.1$ & $30.3 \pm 1.8^{*}$ & $45.5 \pm 2.5 * \#$ & $45.3 \pm 1.6 * \#$ & $48.6 \pm 2.6^{*}$ \\
\hline $\mathrm{NBT}_{\mathrm{CCC}}$ & $30.5 \pm 5.8$ & $42.6 \pm 2.2^{*}$ & $75.6 \pm 3.3^{*}$ & $56.3 \pm 2.5 \#$ & $78.4 \pm 4.3^{*}$ \\
\hline CLP, \% & $78.6 \pm 4.4$ & $83.9 \pm 2.7$ & $88.2 \pm 1.4 *$ & $91.3 \pm 6.2 *$ & $80.4 \pm 5.2$ \\
\hline CLP $_{\mathrm{CCC}}$ & $122.2 \pm 7.1$ & $115.1 \pm 8.9$ & $142.1 \pm 5.9 * \#$ & $111.8 \pm 9.0 * \#$ & $120.4 \pm 8.2 \#^{\wedge}$ \\
\hline
\end{tabular}

Note: $*$ - the difference is significant in relation to the value in the control group $(p<0,05) ; \#$ - the difference is significant in relation to the value in the group of patients with $A M(p<0.05) ;{ }^{\wedge}-$ the difference is probable in relation to the value in the group of patients with APA $(p<0.05)$

Activation of intracellular microbicidal systems of neutrophils was revealed. In patients with AM, the percentage of NBT-positive neutrophils was 1.3 times higher, in patients with destructive forms of AA and blood pressure -2 times higher than in healthy groups $(p<0.05)$. There was no difference in the number of NBT-positive neutrophils between the groups with phlegmonous and gangrenous forms of appendicitis.

The number of CLP-containing neutrophils was also higher in destructive forms of AA, and in AM and AT - did not differ from the value in the control group.

\section{Discussion of research results}

In the light of modern scientific knowledge, neutrophils are a unique multipotent population of cells of the immune system, which, in addition to phagocytosis, links between innate and adaptive immunity. Discovery of V. Brinkman et al. In 2004, neutrophil extracellulat traps (NETs) marked the beginning of a new phase in understanding the life cycle, neutrophil functions, and their role in immune defense [11]. Neutrophils play an important role in the development of bactericidal and cytolytic reactions in inflammation, they are the first to come into contact with the pathogen, are very mobile and 
act quickly. As a result of the secretion of "respiratory explosion" products, degranulation is also possible extracellular cytolysis, which is important in antibacterial immunity [10]. Activated phagocytes are highly efficient cytotoxic cells. Our studies have shown that under conditions of acute inflammation, which is pathomorphologically destructive (acute phlegmonous and gangrenous appendicitis), and under conditions of specific inflammation (abdominal tuberculosis), the phagocytic activity of neutrophils is reduced compared to control values. In conditions of nonspecific inflammation of the mesenteric lymph nodes - does not differ from the control indicator. It is known that AA is associated with increased activity of opportunistic flora, abdominal tuberculosis - with mycobacteria, while acute mesadenitis is predominantly viral in nature and neutrophils and phagocytosis are not effective [12]. A study by Warren E. et al. [13] also found a decrease in phagocytic activity of neutrophils in abdominal tuberculosis. Also, our previous studies of phagocytosis in acute cholecystitis indicate a decrease in phagocytic activity of neutrophilic granulocytes [14].

Of great importance in anti-infective protection belongs to the bactericidal properties of phagocytes, which is manifested intracellularly in phagolysosomes after phagocytosis of microorganisms. At this stage, the mechanisms of bactericidal properties of the phagocyte and their activation are important. The most powerful mechanism is the formation of reactive oxygen species and halogens, which have a pronounced bactericidal effect. An available laboratory method for detecting the formation of reactive oxygen species is a cytochemical test with terazolium nitro blue (NBT test) [10]. At the present stage of development, laboratory medicine has two analytical approaches to the detection of redox processes in neutrophils: cytochemical test, which is simple and cheap to perform, and flow cytometry [15-17]. As a result of our studies on the background of reduced phagocytic activity in patients with destructive forms of acute appendicitis and abdominal tuberculosis, we observed the activation of redox processes in blood neutrophils, as indicated by increased spontaneous NBT-test. Giese M. A. and sang. indicate that a decrease in phagocytic (endocytic) activity of phagocytes simultaneously with an increase in their oxygen-dependent metabolism is a sign of classical, pro-inflammatory (phenotype N1) activation. Neutrophilic granulocytes with proinflammatory activity (N1) synthesize a large number of proinflammatory mediators and promote the activation of CD8 + lymphocytes, increase their production of reactive oxygen species and nitric oxide and result in the development of inflammation, induction by synthesis of proinflammatory cytokines [18]. The literature also describes the activation of neutrophils in tuberculosis infection $[2,19,20]$.
Thus, the cytochemical NBT test is an accessible and informative laboratory test that can be used for the differential diagnosis of acute destructive inflammation from non-bacterial inflammation.

Cytochemical test for cationic lysosomal proteins determines the presence of oxygen-independent mechanisms of bactericidal neutrophils. The group of these proteins includes $\alpha$-defensins, which are synthesized and packaged in granules during neutrophil differentiation $[21,22]$. We found that in acute destructive inflammation of AO slightly increased percentage of neutrophils containing cationic lysosomal proteins, while in other pathologies the indicator did not differ from the control value.

Thus, our studies using available laboratory cytochemical methods to determine the activity of phagocytosis and neutrophil metabolism in whole blood showed that phagocytes show a high oxidative potential (metabolic reserve), but disrupted the process of recognition and absorption (phagocytosis). That is why the functional activity of granulocytes should be assessed comprehensively. Carrying out the reaction in whole blood (granulocytes are not subject to preliminary selection and washing), in the presence of opsonizing factors of serum, greatly increases the objectivity of the study.

Study limitations. The limitations of the study are related to the small cohort of examined patients.

Prospects for further research. A study to detect neutrophilic extracellular traps in inflammation is planned.

\section{Conclusions}

1. As a result of research it is established that neutrophilic granulocytes of peripheral blood in conditions of acute inflammation have reduced absorption function with simultaneous significant activation of redox processes and increase the number of lysosomal granules with cationic proteins in cells.

2. In conditions of chronic specific inflammation, the decrease in the absorptive function of neutrophils is accompanied by an increase in redox activity, and the content of cationic lysosomal proteins does not differ from that in healthy individuals.

3. Cytochemical tests to detect phagocytic and metabolic activity of blood neutrophils are available and highly informative for the diagnosis and prediction of inflammation, as well as for the differential diagnosis of bacterial and viral diseases.

\section{Conflict of interests}

The authors declare that they have no conflicts of interest.

\section{Referenses}

1. Chawla, L. S., Toma, I., Davison, D., Vaziri, K., Lee, J., Lucas, R. et.al. (2016). Acute appendicitis: transcript profiling of blood identifies promising biomarkers and potential underlying processes. BMC Medical Genomics, 9(1). doi: http://doi.org/10.1186/s12920-0160200-y

2. Tian, G., Xiao, Y., Chen, B., Guan, H., Deng, Q. Y. (2010). Multi-site abdominal tuberculosis mimics malignancy on18FFDG PET/CT: Report of three cases. World Journal of Gastroenterology, 16 (33), 4237. doi: http://doi.org/10.3748/wjg.v16.i33.4237

3. Abu-Zidan, F. M., Sheek-Hussein, M. (2019). Diagnosis of abdominal tuberculosis: lessons learned over 30 years: pectoral assay. World Journal of Emergency Surgery, 14 (1). doi: http://doi.org/10.1186/s13017-019-0252-3

4. Petrov, R. V., Khaitov, R. M., Chereshnev, V. A. (2017). Fiziologiia immunnoi sistemy: kletochnye i molekuliarnobiologicheskie mekhanizmy. Vestnik Rossiiskogo fonda fundamentalnykh issledovanii, 1, 96-119. 
5. Muefong, C. N., Sutherland, J. S. (2020). Neutrophils in Tuberculosis-Associated Inflammation and Lung Pathology. Frontiers in Immunology, 11. doi: http://doi.org/10.3389/fimmu.2020.00962

6. Witko-Sarsat, V., Pederzoli-Ribeil, M., Hirsh, E., Sozzani, S., Cassatella, M. A. (2011). Regulating neutrophil apoptosis: new players enter the game. Trends in Immunology, 32 (3), 117-124. doi: http://doi.org/10.1016/j.it.2011.01.001

7. Kolaczkowska, E., Kubes, P. (2013). Neutrophil recruitment and function in health and inflammation. Nature Reviews Immunology, 13 (3), 159-175. doi: http://doi.org/10.1038/nri3399

8. Amulic, B., Cazalet, C., Hayes, G. L., Metzler, K. D., Zychlinsky, A. (2012). Neutrophil Function: From Mechanisms to Disease. Annual Review of Immunology, 30 (1), 459-489. doi: http://doi.org/10.1146/annurev-immunol-020711-074942

9. Matviichuk, B. O., Bochar, V. T., Pater, Ya. Z., Danylko, V. M., Zhinko, V. V., Kovalyshyn, M. I. et. al. (2014). Uskladnennia riznykh form tuberkulozu $\mathrm{v}$ umovakh zahalnokhirurhichnoho statsionaru. Naukovyi visnyk Uzhhorodskoho universytetu. Seriia: Medytsyna, 2 (50), 94-98.

10. Lapovets, L. Ye., Lutsyk, B. D., Lebed, H. B. et. al. (2014). Posibnyk z laboratornoi imunolohii. Lviv, 320.

11. Podolska, M. J., Mahajan, A., Hahn, J., Knopf, J., Maueröder, C., Petru, L. et. al. (2019). Treatment with DNases rescues hidden neutrophil elastase from aggregated NETs. Journal of Leukocyte Biology, 106 (6), 1359-1366. doi: http://doi.org/10.1002/jlb.3ab0918-370r

12. Mandavdhare, H. S., Singh, H., Sharma, V. (2017). Recent advances in the diagnosis and management of abdominal tuberculosis. EMJ Gastroenterol, 6 (1), 52-60.

13. Warren, E., Teskey, G., Venketaraman, V. (2017). Effector Mechanisms of Neutrophils within the Innate Immune System in Response to Mycobacterium tuberculosis Infection. Journal of Clinical Medicine, 6 (2), 15. doi: http://doi.org/10.3390/jcm6020015

14. Lapovets, L. E., Akimova, V. M., Lutsiv, N. Z. (2012). Funktsionalna aktyvnist neitrofilnykh hranulotsytiv pry hostromu kholetsystyti. Visnyk problem biolohii i medytsyny, 1, 146-148.

15. Tvrda, E. (2019). NBT test. Oxidants, Antioxidants and Impact of the Oxidative Status in Male Reproduction. Academic Press, 195-205. doi: http://doi.org/10.1016/b978-0-12-812501-4.00018-3

16. Aitken, R. J. (2018). Nitroblue tetrazolium (NBT) assay. Reproductive BioMedicine Online, 36 (1), 90-91. doi: http://doi.org/10.1016/j.rbmo.2017.09.005

17. Pattan, S. S., Bhat, K. G., Pattar, G. D., Kuntagi, M. (2020). Comparison of three different techniques for isolation of neutrophils from blood and their utility in performing nitroblue tetrazolium test. International Journal of Research GRANTHAALAYAH, 7 (12), 115-122. doi: http://doi.org/10.29121/granthaalayah.v7.i12.2019.305

18. Giese, M. A., Hind, L. E., Huttenlocher, A. (2019). Neutrophil plasticity in the tumor microenvironment. Blood, 133 (20), 2159-2167. doi: http://doi.org/10.1182/blood-2018-11-844548

19. Muefong, C. N., Sutherland, J. S. (2020). Neutrophils in Tuberculosis-Associated Inflammation and Lung Pathology. Frontiers in Immunology, 11. doi: http://doi.org/10.3389/fimmu.2020.00962

20. Su, R., Peng, Y., Deng, Z., Deng, Y., Ye, J., Guo, Y. et. al. (2019). Mycobacterium tuberculosis Infection Induces LowDensity Granulocyte Generation by Promoting Neutrophil Extracellular Trap Formation via ROS Pathway. Frontiers in Microbiology, 10. doi: http://doi.org/10.3389/fmicb.2019.01468

21. Rane, D., Patil, T., More, V., Patra, S. S., Bodhale, N., Dandapat, J., Sarkar, A. (2018). Neutrophils: Interplay between host defense, cellular metabolism and intracellular infection. Cytokine, 112, 44-51. doi: http://doi.org/10.1016/j.cyto.2018.07.009

22. Hemshekhar, M., Anaparti, V., Mookherjee, N. (2016). Functions of Cationic Host Defense Peptides in Immunity. Pharmaceuticals, 9 (3), 40. doi: http://doi.org/10.3390/ph9030040

Received date 17.08.2020

Accepted date 25.09.2020

Published date 30.11.2020

Viorika Akimova, Doctor of Biological Sciences, Associate Professor, Department of Clinical Laboratory Diagnostic, Danylo Halytsky Lviv National Medical University, Pekarska str., 69, Lviv, Ukraine, 79010

E-mail: viorikakimova.kld@gmail.com

Lyubov Lapovets, MD, Professor, Head of Department, Department of Clinical Laboratory Diagnostic, Danylo Halytsky Lviv National Medical University, Pekarska str., 69, Lviv, Ukraine, 79010

E-mail: lapovets@ukr.net

Lapovets Nataliia, PhD, Senior Research Fellow, Research Institute of Epidemiology and Hygiene, Danylo Halytsky Lviv National Medical University, Pekarska str., 69, Lviv, Ukraine, 79010

E-mail: natla@ukr.net

Oksana Tsymbala, PhD, Associate Professor, Department of Clinical Laboratory Diagnostic, Danylo Halytsky Lviv National Medical University, Pekarska str., 69, Lviv, Ukraine, 79010

E-mail: oksanatcymbala@gmail.com 